\title{
Forecasting the labour market by occupation and education: some key issues
}

Citation for published version (APA):

Cörvers, F., \& Heijke, J. A. M. (2004). Forecasting the labour market by occupation and education: some key issues. Researchcentrum voor Onderwijs en Arbeidsmarkt, Faculteit der Economische Wetenschappen. ROA Working Papers No. 4 https://doi.org/10.26481/umarow.2004004

Document status and date:

Published: 01/01/2004

DOI:

10.26481/umarow.2004004

Document Version:

Publisher's PDF, also known as Version of record

\section{Please check the document version of this publication:}

- A submitted manuscript is the version of the article upon submission and before peer-review. There can be important differences between the submitted version and the official published version of record.

People interested in the research are advised to contact the author for the final version of the publication, or visit the DOI to the publisher's website.

- The final author version and the galley proof are versions of the publication after peer review.

- The final published version features the final layout of the paper including the volume, issue and page numbers.

Link to publication

\footnotetext{
General rights rights.

- You may freely distribute the URL identifying the publication in the public portal. please follow below link for the End User Agreement:

www.umlib.nl/taverne-license

Take down policy

If you believe that this document breaches copyright please contact us at:

repository@maastrichtuniversity.nl

providing details and we will investigate your claim.
}

Copyright and moral rights for the publications made accessible in the public portal are retained by the authors and/or other copyright owners and it is a condition of accessing publications that users recognise and abide by the legal requirements associated with these

- Users may download and print one copy of any publication from the public portal for the purpose of private study or research.

- You may not further distribute the material or use it for any profit-making activity or commercial gain

If the publication is distributed under the terms of Article $25 \mathrm{fa}$ of the Dutch Copyright Act, indicated by the "Taverne" license above, 
Forecasting the labour market by occupation and education:

Some key issues

ROA-W-2004/4

Frank Cörvers, Hans Heijke

Researchcentrum voor Onderwijs en Arbeidsmarkt

Faculteit der Economische Wetenschappen en Bedrijfskunde Universiteit Maastricht

Maastricht, december 2004 
ISBN 90-5321-401-1

Sec04.122 


\section{Contents}

Abstract

Acknowledgement

1 Introduction 1

2 Gaps 3

3 Substitution 6

4 The relevance of substitution illustrated 9

5 Conclusions 14

References 



\begin{abstract}
In this paper, we focus on two key characteristics of ROA's forecasting approach of the labour market by occupation and education. These concern the use of the gap approach, and the substitution of education programmes within occupations. We show that the gap between supply and demand constitutes a useful and informative concept, which can be justifiably used as long as too little is known about the adjustment process in the labour market. Then we discuss the structure of the substitution process, mainly focusing on substitution as a result of the initially expected gaps between supply and demand. We distinguish between active substitution, resulting from supply-demand mismatches for the education programme concerned, and passive substitution, which is due to spillover effects from supply-demand mismatches for other education programmes. Passive substitution between education programmes is included in the forecasts when the final gaps between supply and demand are calculated. Recent ROA forecasts are used to illustrate the meaning of the various substitution processes for expected labour demand and the gaps between supply and demand. We find that omitting substitution demand from the forecasting model results in future labour market prospects that are generally too pessimistic for the higher educated.
\end{abstract}

\title{
Acknowledgement
}

We would like to thank the participants of the conference 'Modelling labour market: Realities and prospects', organised by Employment Observatory Research Informatics in Athens, 31 October 2003, for their comments on an earlier version of this paper. 



\section{Introduction}

In his famous example of the pin factory, Adam Smith showed us more than two centuries ago how labour specialisation increases productivity. Division of labour is a major source for the development of prosperity in a country. The education system not only offers citizens a general preparation for social life but also prepares them for more or less specialised roles in the labour market. Depending on their abilities and ambitions, pupils and students remain in the education system for a shorter or longer period of time. They enter the labour market with different levels and types of knowledge and skills. These given them comparative advantages for their successful performance of certain roles within the division of labour, for example in the occupations of butcher, skilled labourer, teacher, employee, or physician. School-leavers and graduates who manage to obtain occupations that match their education, generate an optimal economic value.

This statement can also be reversed: when making efforts to achieve optimal economic development, it is important that sufficient numbers of school-leavers with the required knowledge and skills enter the labour market to successfully take the available jobs. As a result of the great uncertainty regarding future returns, the major social component in these returns, and insufficient accessibility of the capital market for investments in education, it is doubtful whether the required investments in education will be made without any external intervention. During the 1960s, the method of manpower planning was developed as a tool for determining the required investments in education. Under the auspices of the OECD, Parnes (1962) created a model in which a particular target growth of GDP over a number of years was taken to derive the labour requirements, first by sector, then by occupation per sector, and finally by education per occupation. The labour requirements for each education programme are compared with forecasts of the working population by education and the outflows from the various levels and types of education to the labour market. This comparison then produces the need for the additional educational initiatives that are required to achieve the GDP growth targets.

The manpower planning approach has been criticised widely. The main points of criticism were that developments in the labour market were too unpredictable and that the models used assumed a one-to-one relationship between occupation and education, leaving too little room for any substitution and other adjustment processes in the case of expected labour market imbalances (Blaug, 1967). An alternative solution was proposed, which was based on a more flexible approach to education. Initial education programmes would have to be broadened in such a way that they could prepare for a wide range to occupations. After finding a job, the discrepancy that remained between the knowledge and skills obtained in education and the knowledge and skills required for a proper performance in an occupation, would have to be eliminated by means of short training courses and on-the-job training. This broadening of the scope of education should make it easier to find a job after leaving the education system, resulting in fewer discrepancies between supply and demand in submarkets. This proposal was also criticised widely. With unrestricted broadening of education, the productivity advantages of division of labour can only be achieved by employers paying the price of high adjustment costs. The idea is to find the optimal trade-off 
between flexibility and productivity (see e.g. Heijke and Borghans, 1998). The result will always make a certain degree of differentiation in education desirable, with uncertain future returns.

The idea that the need for educational facilities can be planned accurately, has now been abandoned. The need for well-founded labour market forecasts, differentiated by occupation and education, however, has remained. To be able to effectively focus new investments in education and training, the deployment of labour market instruments, and policy development in the field of personnel and human resources management, on the possibilities of the labour market, we need indicators for the labour market perspectives of the groups involved. The need for labour market forecasts has also become rooted in the world of study and career planning. The idea here is that these forecasts may help individuals who need to choose a study, by matching their expectations to actual realisation in the labour market position of the education chosen, thus decreasing the chances of regrets after graduation. The present focus in labour market forecasting is therefore more on increasing the transparency of labour market developments for the various parties who are interested in a good match between education and the labour market, than on a comprehensive planning of required facilities in this field.

Labour market forecasts, differentiating by occupation and education, are now being created at regular intervals in a number of countries. The methods used are generally more refined than the traditional manpower planning approach, but often do not differ from this approach in essence. The labour market variables that are being forecast, are not the same ones in all cases. It is possible to restrict oneself to forecasting the future development of employment by economic sector and occupation, or alternatively to include the development of supply, in particular the outflow from the educational system. The differentiations used may also differ, not merely by degree but also by type. One may restrict oneself to economic sectors and occupations, or add education programmes. For more information on the approach used in a number of European countries, see for example Heijke (1994), and more recently Neugart and Schömann (2002).

In the Netherlands, the Research Centre for Education and the Labour Market (ROA) of Maastricht University has been making forecasts of the developments in supply and demand in the labour market, differentiated by occupation and education, for more than fifteen years. Each forecast covers a period in the future of five years, and they are made every two years. The forecasts made are used to create policy-oriented reports and to provide information, often in the form of data files, to ministries and institutions in the field of education and the labour market, and to publishers of study and career advice material.

The ROA forecasts have the following characteristics:

- The forecasts cover the entire labour market and are highly differentiated. They distinguish 13 economic sectors, 127 occupational groups and 104 types of education (including 6 levels). 
- Contrary to the traditional manpower planning model, the models used for the occupational structure of economic sectors are flexible. They describe the shifts over time and contain not only trend variables, but also explanatory variables. ${ }^{1}$

- The education model describes not only the autonomous shifts in the educational structure of occupations (skills upgrading and downgrading), but also the substitution of education programmes as a result of gaps between supply and demand.

- With reference to the traditional manpower planning approach, the forecasts also focus on future gaps between supply and demand, differentiated by education.

- Because the forecasts must be easy to interpret by individuals choosing a study and to avoid the pretence of certainty, the quantified forecasting results with respect to the gaps are plotted on a qualitative scale, ranging from 'very good', through 'good', 'reasonable', 'moderate', and 'poor' to 'very poor'.

In this paper, we will focus on two of these characteristics. These concern the use of the gap approach, and the substitution of education programmes within occupations. These are two, mutually dependent, key issues in making labour market forecasts. In Section 2, we will show that the gap between supply and demand constitutes a useful and informative concept, which can be justifiably used insofar as not enough is known about the adjustment process in the labour market. In Section 3, we will discuss the various substitution processes between education programmes in the labour market, and in particular the structure of the substitution process as a result of the initially expected gaps between supply and demand. We distinguish between active and passive substitution. The passive substitution between education programmes is included in the forecasts when the final gaps between supply and demand are calculated. Section 4 uses recent ROA forecasts to illustrate the meaning of the substitution processes in the labour market for the expected labour demand and the gaps between supply and demand. In Section 5, we will draw our conclusions.

\section{Gaps}

ROA's labour market forecasts result in predictions of future gaps between supply and demand per type of education. Following on the traditional manpower planning approach, no account is taken of any wage adjustments that might restore the balance between supply and demand. This may seem incorrect, because a wage increase anticipating an expected labour shortage may trigger additional supply and thus eliminate part of the demand, and hence the initially expected shortage will not occur. It is, however, the question whether the adjustment process in the labour market works as simple as that. In practice, the required adjustments will be achieved only partly through the wage mechanism. A labour shortage can also be eliminated, for example, by closing more permanent employment contracts in the educational submarket concerned, by increasing the working time factor of the available jobs, or by recruiting more workers from other types of education (see Wieling and Borghans, 2001). Not in the last place - and in fact quite relevant within the framework of the purpose of this type of forecasts - additional supply may be elicited by expanding the

1. The forecasts of economic sector developments were taken from the CPB Netherlands Bureau for Economic Policy Analysis, which uses an advanced economic sector model for its calculations. 
capacity of the study programme concerned. Insofar as it cannot be made explicit in the models used how the adjustments will take place, the predicted gap between supply and demand constitutes a useful indicator of the total extent to which the submarket concerned will need to adjust to an increasing imbalance between supply and demand. Only when more is known about the type and intensity of adjustments in the labour market to imbalances between demand and supply, an expected labour shortage in an educational submarket could be expressed in terms like the expected increases of wage, working time, permanent employment and supply from other types of education.

Figure 1

Relationship between gap and wage adjustment for a predicted shift in supply

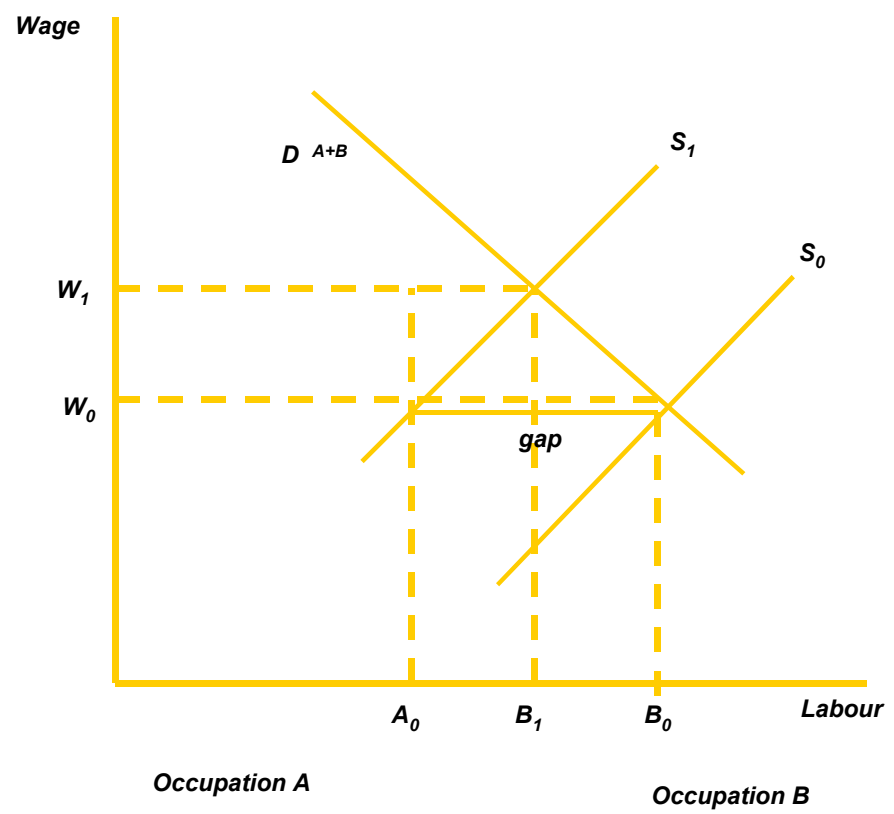

Source: de Grip, Borghans and Smits (1998)

That there is a direct relationship between the size of the gap and the degree of adjustment that is necessary to restore the equilibrium, can be illustrated with Figure 1. This figure relates to a particular educational submarket. The vertical axis shows the wages $(w)$, while the horizontal axis contains the demanded and supplied amounts of labour ( $D$ and $S$, respectively). The demand includes both the demand in the occupation (A) that is most appropriate for the education, and the demand in an alternative occupation (B) for the education. For the sake of simplicity, we have assumed that adjustment takes place entirely through the wage mechanism. We will now assume that in the starting position, the submarket concerned is in equilibrium. This situation is represented by the intersection of the demand curve $D^{A+B}$ and the supply curve So where wages equal $w_{0}$. There will then be $A_{0}$ individuals with the education concerned who work in occupation $A$, and $A_{0} B_{0}$ individuals in occupation $B$. We will now assume that according to the forecasts, the supply will drop from $S_{0}$ to $S_{1}$. If the wage base $w_{0}$ remains the same, a labour shortage of $A_{0} B_{0}$ individuals will arise. In our example, this means that no more individuals of the education programme 
concerned can be recruited in the alternative occupation $B$. To fully eliminate the gap $A_{0} B_{0}$ that has emerged, wages will need to rise to $w_{1}$. It is not difficult to see that as the gap is greater, the required wage increase will also need to be greater in order to restore the equilibrium in the educational submarket concerned. There is therefore a direct relationship between the size of the gap and the required degree of (wage) adjustment.

The above can also be represented by using some math (cf. Heijke and de Grip, 1995). Assuming the following labour market model:

$S=\gamma+\alpha w$

$D=\delta-\beta w$

The equilibrium wage equals:

$w_{e}=\frac{\delta-\gamma}{\alpha+\beta}$

The required wage adjustment is then:

$w_{e}-w=\frac{D-S}{\alpha+\beta}$

It is therefore true that there is a direct relationship between gap and required adjustment. The greater the gap, the greater the required wage adjustment, with the intensity of the relationship being determined by the sum of wage elasticities of supply and demand.

Often, the size of the gap between supply and demand gives rise to the incorrect conclusion that the supply will need to change in the same order of magnitude as the shortage or surplus in order to restore the equilibrium. For example, in the case of a forecasted shortage of $x$ teachers, the conclusion is often that $x$ additional teachers need to be trained. What is overlooked, is the fact that the adjustment mechanism will automatically eliminate part of the shortage. ${ }^{2}$ If we assume again that only the wage mechanism applies, then it is easy to deduce from the labour market model above that the additional supply to be created, is determined by:

$S_{e}-S=\frac{\alpha}{\alpha+\beta}(D-S)$

The relation between the wage elasticity of supply and the wage elasticity of demand plays a major role here. The greater the wage elasticity of demand, the smaller the part of the gap that needs to be closed by creating additional supply in order to restore the equilibrium. What the - premature - policy conclusion discussed above overlooks, therefore, is the decrease of demand as a result of the wage base increase.

2. Cf. part $B_{1} B_{0}$ in gap $A_{0} B_{0}$ in Figure 1. 
The forecasted future gaps between supply and demand in submarkets therefore indeed provide information on the future situation in those submarkets. The gaps provide insight in the size of the adjustment that is required in order to restore the equilibrium between supply and demand. This does not answer the question how exactly this adjustment will take place. The latter requires greater insight in the effects of the wage mechanism on the restoration of the equilibrium and the degree to which the adjustment takes place through other labour conditions, such as working hours and permanency of contracts, and through factors such as study choice and spillover to other educational submarkets. A major problem here is that the statistical data needed to estimate the adjustment reactions, are often not available. In the ROA forecasts, however, we have developed an approach that allows us to take into account any spillover into other submarkets resulting from predicted gaps. This substitution issue will be discussed in the next section.

\section{Substitution}

One of the objections to the traditional manpower planning approach is the absence of substitution between education programmes. In reality, we see new education programmes emerging and disappearing in the labour market, following the changes in occupational structures. We also see the levels and types of education programmes that are demanded changing within occupations. Not only are technological and organisational developments changing the occupational structures of economic sectors, resulting in different education programmes being required in those sectors, but there is also upgrading and downgrading of occupations, which makes them demand higher or lower education levels, respectively. In addition, the content of occupations may change in such a way that different types of education enter the scene for those who take those occupations. Apart from substitution caused by this so-called skill-biased technological change, substitution may also take place between levels and types of education as a reaction to changes in scarcity levels between educational submarkets. Workers with educational backgrounds of whom there is a surplus, will try to find work in occupations in which workers are employed with educational backgrounds of which there is a shortage. Also, in the case of surpluses in occupations for the higher educated, there may be a flight into occupations at lower levels, at the expense of the lower educated already working there. This is the so-called bumping-down process. Because the changes of the educational structure that were triggered by technological developments affect the scarcity relationships between education programmes, technological developments have an indirect effect on the substitution resulting from changing scarcity relationships.

ROA's labour market forecasts take these substitution processes between education programmes into account (see Cörvers, de Grip and Heijke, 2002). This means that they include the shifts in the occupational structure and upgrading and downgrading of occupations caused by technological developments, as well as the substitution of education programmes caused by shortages and surpluses in educational submarkets.

The effects of technological developments are determined in two steps. The first step concerns the change of the occupational structure of economic sectors. This is related in the 
forecasting models used to the change of sectoral production capacity and the course of time. The second step forecasts the change of the future educational structure of occupations. It is assumed that the level of education required concentrates around the average level in the occupation and that there is downward displacement because the higher educated are generally preferred to the lower educated.

Figure 2

Substitution caused by a gap between supply and demand

Education

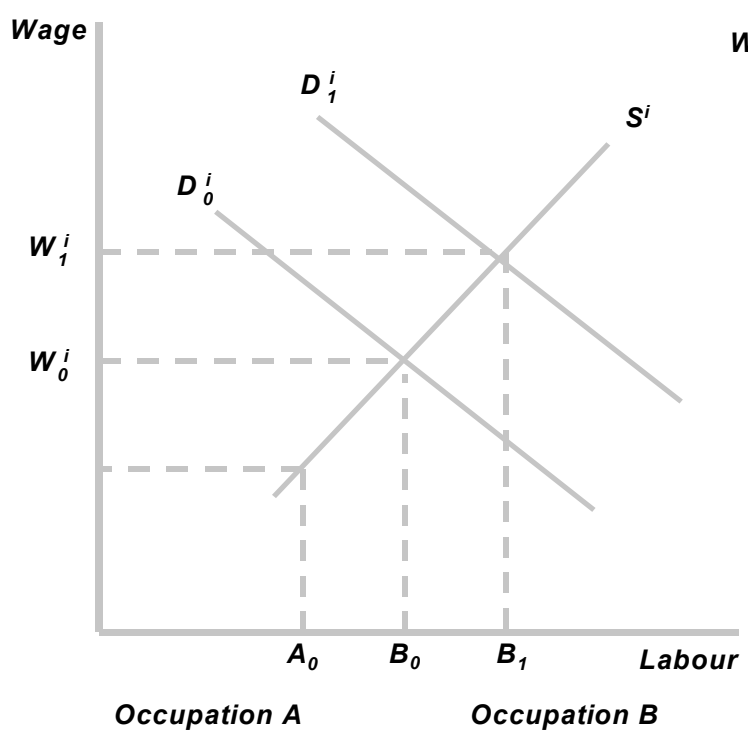

Education $_{j}$

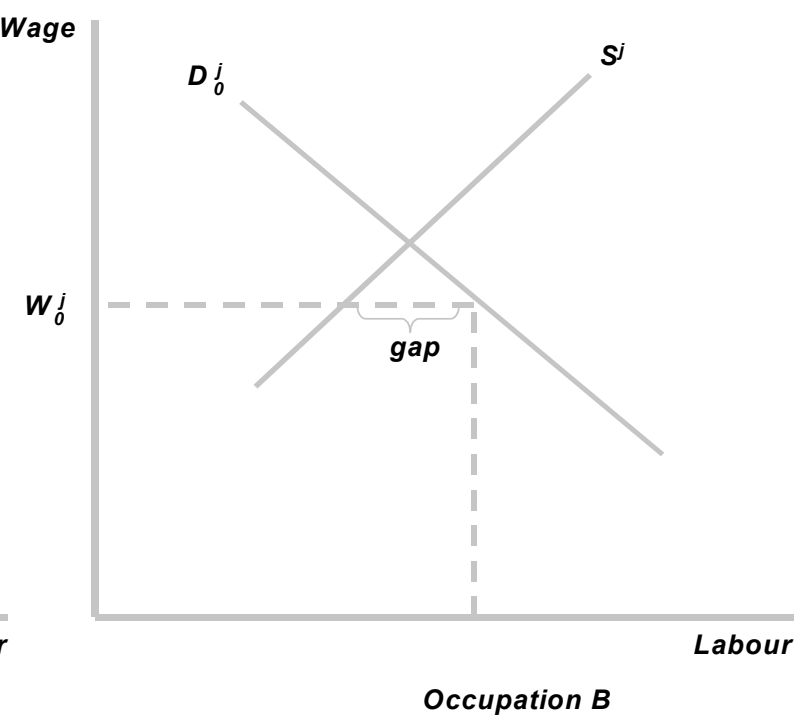

Source: de Grip, Borghans and Smits (1998)

Before we illustrate how the substitution process caused by the gaps between supply and demand is included in the forecasts, we shall first explain this process on the basis of Figure 2. The vertical axis again shows the wages, while the horizontal axis shows the supply and demand. The figure on the left concerns education programme $i$, for which supply and demand are initially in equilibrium at wage level $w_{0}^{i}$. We have assumed that the majority of the workers $\left(A_{0}\right)$ work in occupation $A$, which matches the education best, while a minority $\left(A_{0} B_{0}\right)$ works in the alternative occupation $B$. The right-hand part of the graph concerns education programme $j$. Here we have assumed that workers with this education only work in occupation B, which matches the education best. The initial forecasts of the developments of supply and demand in this submarket indicate a demand surplus at wage base $w_{0} j$. Graduates from education programme $j$ therefore have good labour market perspectives. However, this will entice workers with education $i$ to also work in occupation B. For them, there is therefore a shift of the demand curve to the right. Wages will increase until a new equilibrium has been reached $\left(w_{1}{ }^{i}\right)$. In this new equilibrium, there will be $B_{0} B_{1}$ more workers with education $i$ working in occupation $B$ than before. As the initiative for this substitution 
stemmed from a shortage on the educational submarket $j$, we call this passive substitution of education $i$. Because of this 'passive' substitution, graduates from education programme $i$ also have good labour market perspectives.

With reference to the above, the substitution reaction to gaps between supply and demand are included in the forecasts by first determining the initial gaps between supply and demand in educational submarkets, and then to simulate the substitution process. Roughly, the process proceeds as follows (for details, see Borghans and Heijke, 1995). In educational submarkets with a supply surplus - so where the labour market position of the education programmes concerned is deteriorating - workers with this educational background switch to different, less attractive, occupations. Reversely, educational submarkets for which a supply shortage is expected in the initial forecast, attract workers with different educational backgrounds, who in fact see the demand for their education increase. It is assumed that the degree to which switching between different occupations takes place in the case of both 'push' and 'pull', is proportional to the distribution of education programmes across these occupations in the preceding period. The gaps between supply and demand that remain after this adjustment process, give rise to a new round of substitutions, which process is repeated until after several iterations an equilibrium has been reached.

In the substitution process described above as a reaction to the gaps between supply and demand, we distinguish two types of substitution; active substitution and passive substitution. Active substitution can be defined as the substitution of an education programme caused by a mismatch between supply and demand in the own educational submarket. In Figure 2, this is represented by a move along the supply and demand curves of education programme $j$ towards their point of intersection. Passive substitution, as indicated above, is the substitution of an education programme resulting from spillover effects of mismatches between supply and demand in other educational submarkets. In Figure 2, this is represented by the outward shift of the demand curve of educational programme $i$. When we determine the final forecasts for gaps between supply and demand in educational submarkets, we only take passive substitution into account, so with the substitution by spillovers from other submarkets. This means that for education programmes that are forced out of their occupational domains by education programmes with an initial surplus, this is regarded as a decreasing demand for these education programmes, and hence a deterioration of their labour market perspectives. On the other hand, we do not regard this replacement as an improvement of the initial labour market position of the replacing education programmes. This would after all lead to an underestimation of the unfavourable labour market perspectives for these education programmes. Reversely, an expansion of the occupational domains of education programmes as a result of workers with an educational background for which an initial shortage is expected leaving these domains, is regarded as an expansion of the demand for the first category of education programmes, and hence as an improvement of their labour market perspectives. Similarly, the pull of education programmes by an initial shortage for these programmes, is not regarded as a deterioration of the initial labour market perspectives of these education programmes. 


\section{The relevance of substitution illustrated}

We will illustrate the relevance of the substitution demand by presenting the labour market forecasts by ROA for the Netherlands from 2003 to 2008. To do so, we will first compare the substitution demand with three components of the expansion demand: the demand changes due to the development of economic sectors, the shift in the occupational structure of economic sectors and the shift in the educational structure of occupations. This analysis focuses on the expected employment shifts between six levels of education. Secondly, we will indicate the share of the substitution demand in the total labour demand for 17 education categories. The total labour demand consists of the expansion and substitution demand as well as the replacement demand. Lastly, we will show the impact of omitting the substitution demand from the forecasting model on the indicator for future labour market prospects of school-leavers and graduates.

Table 1 gives an overview of the four components of the expected future development in employment according to the level of education. The abbreviations of the types of education used in the text and the table are explained in the legend underneath the table. We distinguish the following four components of the employment development:

- differences in the development in employment within economic sectors: the economic sector effect;

- shifts in the occupational structure within economic sectors: the occupational effect;

- changes in the required educational background within occupations: the educational effect. This effect reflects the degree of upgrading within occupations;

substitution demand, which refers to the additional demand (in a positive or negative sense) caused by shortages or excesses in supply of types of education that are related from the point of view of the labour market: the passive substitution effect. This effect reflects how courses of education with excess supply crowd out other courses of education (not necessarily of a lower level), or, conversely, how a lack of supply attracts people with a related educational background. ${ }^{3}$

The first three effects together determine the expansion demand. In addition, the passive substitution effect occurs as a result of the confrontation between the inflow of schoolleavers (supply) on the one hand, and job openings due to expansion and replacement demand (see below) on the other.

The table shows that the differences in the increase in employment between economic sectors have an effect on the shifts in employment structure according to the level of education. A decline in employment is expected for the two lowest levels of education. There is an increase of the economic sector effect with the level of education, from primary education by $-0.8 \%$ to UE by $3.4 \%$. This indicates that knowledge-intensive sectors, in which the knowledge-intensity is approached by the employment structure by level of education, are on average growing more rapidly than less knowledge-intensive sectors. The changes in

3. The active substitution effect is only included in the actual development in employment. 
the intersectoral employment structure indicate that the Netherlands are moving towards a knowledge economy.

Table 1

Components of the expected employment growth by level of education (net effects*), the Netherlands, 2003-2008**

\begin{tabular}{lccccc}
\hline Level of education & $\begin{array}{c}\text { Economic sector } \\
\text { effect } \\
\%\end{array}$ & $\begin{array}{c}\text { Occupational } \\
\text { effect } \\
\%\end{array}$ & $\begin{array}{c}\text { Educational } \\
\text { effect } \\
\%\end{array}$ & $\begin{array}{c}\text { Passive } \\
\text { substitution } \\
\%\end{array}$ & $\begin{array}{c}\text { Total } \\
\%\end{array}$ \\
\hline Primary education & -0.8 & -0.2 & -22.1 & -1.5 & -24.5 \\
PVE & -0.2 & 0.6 & -6.5 & -3.7 & -9.9 \\
IVE & 0.9 & 0.5 & 3.2 & -1.2 & 3.5 \\
HGSE & 1.4 & 1.6 & 6.0 & -0.7 & 3.3 \\
HVE & 2.9 & -0.3 & 5.2 & 3.1 & 10.9 \\
UE & 3.4 & 2.0 & 4.4 & 7.7 & 17.4 \\
Total & 1.1 & & & 0.0 & 1.1 \\
\end{tabular}

PVE = Preparatory Vocational Education;

IVE = Intermediate Vocational Education (including apprenticeships);

HGSE = Higher General Secondary Education (including Pre-University Education);

HVE = Higher Vocational Education;

UE = University Education.

* The percentages in this table relate to the whole period 2003-2008.

** The totals of the occupational effect, the educational effect and the substitution effect are zero in every case, because these figures refer to shifts in employment shares. Thus a positive occupational effect at one educational level necessarily implies a negative effect at another level.

Source: ROA

Less straightforward differences in the employment growth between levels of education are found for the occupational effect. Due to the intrasectoral shifts in occupational structure, the demand for workers educated at HGSE and UE levels is increasing, whereas the demand for workers at the other levels is not far from zero, that is between $-0.2 \%$ for primary education and 0.6 for PVE. This implies that the demand for workers resulting from the occupational effect, is significantly lower for those who completed a vocational education (PVE, IVE and HVE) than for the more generally educated workers (HGSE and UE). Considerable differences between levels of education only begin to show up under the educational effect: for primary education in particular, there is a particularly negative educational effect of no less than $-22.1 \%$, whereas PVE, too, is expected to have a large negative educational effect of $-6.5 \%$. As to people with intermediate and higher education, the positive economic sector effects are reinforced by positive educational effects. In general, the growth of the intrasectoral employment structure is another indication for the development towards a knowledge economy. The expected increase in employment for economic sectors is higher if the average level of education for these economic sectors is higher, whereas, in addition, the average level of education within sectors and occupations is increasing. 
Lastly, the intersectoral and intrasectoral shifts in employment are reinforced by the substitution demand. The table demonstrates that the substitution effect for the period 20032008 is only positive at the two highest levels of education. The substitution demand is $28 \%$ and $44 \%$ of the total expected demand for HVE and UE, respectively. In particular for those with higher education at UE level, the substitution effect is very substantial. This substitution effect results from the large shortages in supply that apply to many types of education within higher education. This gives rise to extra substitution demand for related courses in higher education. The effect is that of a kind of unchecked spread, which causes the problem areas in the labour market to spread over virtually all types of courses in higher education. This implies that the passive substitution effect alters the employment composition both between levels of education and between education categories at the same level of education. This will be discussed in greater detail below.

As mentioned above, the demand in the labour market consists not only of expansion and substitution demand, but also of replacement demand. When workers retire, leave the labour force under an early retirement scheme or due to work disability, withdraw from the labour market temporarily, or switch to another occupation, etc., replacement demand may arise. However, replacement demand only arises if the departure of an employee actually leads to a vacancy for a new entrant. If the departure of a worker is taken as an opportunity to cut employment levels, no replacement demand results. ${ }^{4}$ Actually, these flows out of the labour market are irrelevant for newcomers.

Thus only part of the flows leaving the market generates replacement demand. Moreover, there is an important difference between the replacement demand per occupational class and per type of education, because occupational mobility has an influence on the replacement demand per occupational class, but not on the replacement demand per type of education. Switching occupations has no effect on the educational structure of employment. On the other hand, when workers complete part-time studies for a higher level or a different qualification, it means in fact an outflow of workers to another type of education. In that case, a replacement demand does arise in the educational type under which a worker's previous education was counted.

If employment levels are rising, the expansion demand contributes to the job openings for newcomers in the labour market. If employment levels are declining, job openings for newcomers can only arise due to replacement demand. The negative expansion demand is not included in the job openings, since the expected declining employment - which represents a net outflow - is already accounted for in the replacement demand. As mentioned above, this implies that not all outflow from the labour market results in job openings for newcomers. Table 2 shows for each of the 17 education categories the extent of the substitution demand relative to the job openings from expansion and replacement

4. See Willems, Borghans and de Grip (1997). They show that shrinking employment will be effected completely by higher exit rates of the working population. As could be expected, in particular older workers and women of 25-34 years old leave the labour market when employment is shrinking. The employment decline does not lead to a lower demand for newcomers (i.e. school-leavers). 
demand. ${ }^{5}$ The substitution demand is the additional (positive or negative) demand that arises from the initial discrepancies between job openings and the supply of school-leavers from related types of education.

Table 2

The (positive) expansion demand, replacement demand and substitution demand relative to the expected job openings, the Netherlands, 2003-2008

\begin{tabular}{|c|c|c|c|c|}
\hline Education category & $\begin{array}{c}\text { Positive } \\
\text { Expansion } \\
\text { demand } \\
\%\end{array}$ & $\begin{array}{c}\text { Replacement } \\
\text { demand } \\
\%\end{array}$ & $\begin{array}{c}\text { Job } \\
\text { openings } \\
\%\end{array}$ & $\begin{array}{c}\text { Additional } \\
\text { Substitution } \\
\text { demand* }^{*} \\
\%\end{array}$ \\
\hline Primary education & 0 & 100 & 100 & -6 \\
\hline PVE theory & 0 & 100 & 100 & -10 \\
\hline PVE agriculture and technology & 0 & 100 & 100 & -34 \\
\hline PVE economics & 27 & 73 & 100 & -10 \\
\hline PVE nursing & 0 & 100 & 100 & -6 \\
\hline HGSE & 39 & 61 & 100 & -2 \\
\hline IVE agriculture and technology & 29 & 71 & 100 & -18 \\
\hline IVE economics & 10 & 90 & 100 & 0 \\
\hline IVE service industry and health care & 29 & 71 & 100 & 8 \\
\hline HVE agriculture and technology & 25 & 75 & 100 & 12 \\
\hline HVE economics & 29 & 71 & 100 & 26 \\
\hline HVE teacher training and social studies & 26 & 74 & 100 & 8 \\
\hline HVE paramedical & 52 & 48 & 100 & 8 \\
\hline UE agriculture and technology & 20 & 80 & 100 & 48 \\
\hline UE economics & 43 & 57 & 100 & 40 \\
\hline UE languages and social studies & 32 & 68 & 100 & 19 \\
\hline UE medical & 4 & 96 & 100 & 8 \\
\hline Total (incl. education unknown) & 23 & 77 & 100 & 0 \\
\hline
\end{tabular}

PVE = Preparatory Vocational Education;

IVE = Intermediate Vocational Education (including apprenticeships);

HGSE = Higher General Secondary Education (including Pre-University Education);

HVE = Higher Vocational Education;

UE $=$ University Education.

* The total of the substitution demand is zero because the substitution effect refers to a shift in employment between education categories.

Source: ROA

Expansion demand hardly plays a significant role at the PVE educational level, except for PVE economics. The replacement demand is very high for PVE education categories, since workers with a PVE education relatively often complete part-time studies, in particular in the apprentice system, for a higher level, which generates replacement demand for workers with a PVE education. Furthermore, the substitution demand is negative for the PVE education categories, since higher qualified workers displace less skilled ones with only PVE education from their 'occupational territory'. At the intermediate level of education, the substitution demand is relatively small, except for IVE agriculture and technology. At this level of

5. The 17 education categories comprise 104 types of education. 
education, the substitution demand is a net effect of a positive substitution demand from the occupational territories of the lower education categories on the one hand, and a negative substitution demand from the occupational territories of the higher levels of education on the other. At HVE and UE levels of education, the substitution demand is relatively large for the education categories of agriculture and technology, and economics. This substitution demand is also a result of the demand for workers with similar types of education at the same educational level. Due to the additional substitution demand, the labour market prospects for the lower education categories worsen, whereas the labour market prospects of IVE service industry and health care and the higher education categories improve. This leads to the conclusion that the labour market prospects are too optimistic for the schoolleavers of lower educational levels and too pessimistic for those of higher educational levels when substitution demand is excluded.

It is possible to give an indication of the relevance of the substitution demand for the expected labour market prospects for newcomers to the labour market, differentiated by education category, on the basis of the predicted changes in demand and supply in the labour market. The conclusions on this point are based on the Indicator of Future Labour Market prospects (IFLM) for each education category, which reflects the relationship between the supply of school-leavers and short-term unemployed with that educational background and the corresponding demand. ${ }^{6}$ If the supply of labour is smaller than the demand, and the IFLM is thus less than 1.00, the labour market is characterized as 'good'. If the value of the IFLM is even below 0.85 , this is characterized as 'very good' labour market prospects. On the other hand, if the IFLM lies between 1.00 and 1.05 so that the excess supply is not much greater than the level attributable to labour market friction, this is characterized as 'reasonable' labour market prospects. For higher values of the IFLM, the labour market prospects for that education category are characterized as 'moderate' or, if the IFLM exceeds 1.15, as 'poor'. Such a qualitative characterization in quite broad terms suffices for various purposes, including vocational and educational guidance counselling. Moreover, it prevents too much significance being attached to the exact numbers produced by the equation, which also increases the reliability of the forecasts.

In this paper, the developments in supply and demand in the Netherlands are reflected at the aggregation level of 17 education categories, which comprise 104 types of education. It should be noted that the labour market prospect of a type of education may show a marked difference from the prospect of the education category to which it belongs. In Table 3, the future labour market prospects of school-leavers in 2008 are presented for the 17 education categories distinguished. The table also reveals the sensitivity of the future labour market prospects for the substitution demand by showing the percentages of school-leavers from the 104 types of education for which the characterization of the future labour market prospects changes when substitution demand is not included. The characterization of the future labour market prospects changes for school-leavers from 11 out of 17 education categories. However, although the labour market prospects of almost all school-leavers

6. For a more extensive explanation of the methodology and a further discussion of future labour market prospects, see Cörvers, de Grip and Heijke (2002). 
change in terms of the labour market indicator (IFLM) when omitting the substitution demand, the characterization does not always change. The largest differences in prospects between including and excluding substitution demand are found for UE agriculture and technology, HVE and UE economics, and UE medical. These results are in line with the negative substitution demand for the lower educational levels and the positive substitution demand for the higher educational levels as presented in Tables 1 and 2. At the intermediate level, the results differ across education categories. The table reveals that the substitution demand can have a considerable impact on the judgement of the future labour market prospects for many education categories.

Table 3

Indicator of future labour market prospects (IFLM) of school-leavers and graduates with and without accounting for substitution demand, the Netherlands, 2003-2008

With substitution

Education category
IFLM without substitution School-leavers for whom characterization becomes: $\begin{array}{cc}\text { Worse } & \text { Better } \\ \% & \%\end{array}$ labour market prospects

$\begin{array}{llc}\text { Primary education } & 1.11 & \text { Moderate } \\ & & \text { Moderate } \\ \text { PVE theory } & 1.13 & \text { Poor } \\ \text { PVE agriculture and technology } & 1.16 & \text { Poor } \\ \text { PVE economics } & 1.29 & \text { Poor } \\ \text { PVE nursing } & 1.19 & \text { Moderate } \\ \text { HGSE } & 1.14 & \text { Good } \\ \text { IVE agriculture and technology } & 1.00 & \text { Moderate } \\ \text { IVE economics } & 1.06 & \text { Reasonable } \\ \text { IVE service industry and health care } & 1.05 & \text { Good } \\ & & \text { Reasonable } \\ \text { HVE agriculture and technology } & 0.98 & \text { Good } \\ \text { HVE economics } & 1.05 & \text { Good } \\ \text { HVE teacher training and social studies } & 0.96 & \text { Good } \\ \text { HVE paramedical } & 0.92 & \text { Good } \\ & & \text { Good } \\ \text { UE agriculture and technology } & 0.92 & \text { Good } \\ \text { UE economics } & 0.93 & \\ \text { UE languages and social studies } & 0.94 & \\ \text { UE medical } & 0.99 & \\ & & \end{array}$

\section{Conclusions}

Despite the severe criticism expressed against the manpower planning approach that was developed in the early 1960s, creating labour market forecasts that are differentiated by occupation and education is still very much alive. Over the years, the models have been refined, both with respect to their methodology and with respect to the distinct 
differentiations, but they still show certain characteristics of the traditional manpower planning method. The objective of the forecasts has also shifted, from a comprehensive planning of the need for new education capacity to providing greater transparency of the labour market for all parties that are interested in a good match between education and the labour market.

Forecasts of the developments in the labour market over the next five years are made in the Netherlands by ROA every two years. Those forecasts are differentiated by a large number of occupations and education programmes. They are used both for policy-making and to provide information to those who are in the process of choosing a study. Although the models use the traditional demand-supply gap approach, they take into account the occurrence of a variety of change processes in the structure of employment and their causes. There is a great deal of attention in particular for the effects of technological developments on the occupational and educational structures of the demand for labour and the substitution between education programmes. Expressing future labour market perspectives in terms of demand-supply gaps can be justified insofar as there is insufficient insight in the adjustment processes in the labour market. The gaps provide useful information on the overall adjustment required in educational submarkets in order to achieve an equilibrium between supply and demand. The ROA forecasts in fact take into account the effects of substitution between education programmes by an initially forecasted mismatch in educational submarkets, with respect to the level of the eventually forecasted demandsupply gaps.

The relevance of the substitution demand is illustrated by presenting the labour market forecasts for the Netherlands from 2003 to 2008. It is shown that the so-called passive substitution effect can be substantial for in particular the higher education categories. Although replacement demand is by far the largest component in total labour demand at the lower and intermediate level of education, the substitution demand significantly contributes to labour demand for higher educated workers. Substitution demand turns out to be negative for the education categories at the lower levels, since the more highly qualified workers displace the less skilled from their 'occupational territory'. Omitting the substitution demand in the forecasting model results in future labour market prospects for school-leavers and graduates that are in general too pessimistic for the higher educated.

\section{References}

Blaug, M. (1967), 'Approaches to educational planning', Economic Journal, 77 (June), 26287.

Borghans, L. and H. Heijke (1996), 'Forecasting the Educational Structure of Occupations: A Manpower Requirement Approach with Substitution', Labour, 10 (1), 151-192.

Cörvers, F., A. de Grip and H. Heijke (2002), 'Beyond manpower planning: a labour market model for the Netherlands and its forecasts to 2006', in M. Neugart and K. Schömann (eds.), Forecasting Labour Markets in OECD Countries, Cheltenham (UK) and Northampton MA (USA): Edward Elgar, pp. 185-223. 
Grip, A. de, L. Borghans and W. Smits (1998), 'Future developments in the job level and domain of high-skilled workers', in H. Heijke and L. Borghans (eds.), Towards a Transparent Labour Market for Educational Decisions, Aldershot (UK), Brookfield (USA), Singapore and Sydney: Ashgate, pp. 21-56.

Heijke, H. (ed.) (1994), Forecasting the Labour Market by Occupation and Education, Boston, Dordrecht and London: Kluwer Academic Publishers.

Heijke, H. and A. de Grip (1995), 'Mismatches Between Education and the Labour Market', in T. Jaspers, J. Schippers, J. Siegers and I. van Berkel (eds.), Working Policies?, Facts, analyses and policies concerning employment and non-participation in the Netherlands, Groningen: Wolters-Noordhoff, pp. 51-80.

Heijke, H. and L. Borghans (1998), 'Investing in education', in H. Heijke and L. Borghans (eds.), Towards a Transparent Labour Market for Educational Decisions, Aldershot (UK), Brookfield (USA), Singapore and Sydney: Ashgate, pp. 1-18.

Neugart, M and K. Schömann (eds.) (2002), Forecasting Labour Markets in OECD Countries, Cheltenham (UK) and Northampton MA (USA): Edward Elgar.

Parnes, H.S. (1962), Forecasting Educational Needs for Economic and Social Development, Paris: OECD.

Wieling, M. and L. Borghans (2001), 'Discrepancies between supply and demand and adjustment processes in the labour market', Labour, 15 (1), 33-56.

Willems, E., L. Borghans and A. de Grip (1997), Exit or no entry? Replacement demand and shrinking employment, Paper for the EALE conference, Aarhus, Denmark. 